\title{
Inner Alpine conifer response to 20th century drought swings
}

\author{
Pascale Affolter • Ulf Büntgen · Jan Esper • \\ Andreas Rigling • Pascale Weber · Jürg Luterbacher • \\ David Frank
}

Received: 29 May 2009/Revised: 7 October 2009/Accepted: 28 October 2009/Published online: 26 November 2009

(C) Springer-Verlag 2009

\begin{abstract}
Tree rings from the Alpine area have been widely used to reconstruct variations in summer temperature. In contrast, estimates of changes in the hydrological cycle are rather scarce. In order to detect altitudinal and species-specific patterns of growth responses to anomalous dry and wet conditions, a large network of 53 tree-ring width site chronologies along the Rhone valley (Valais, Switzerland) covering the 1751-2005 period was compiled and analyzed. A total of 1,605 measurement series from four conifer species—-pine, larch, spruce, fir — were detrended to allow inter-annual to multi-decadal scale variability to be preserved. Site chronologies were combined to four altitudinal (colline: $<800 \mathrm{~m}$ asl, sub-montane: $800-1,000 \mathrm{~m}$ asl, montane: $1,000-1,450 \mathrm{~m}$ asl, sub-alpine: $>1,450 \mathrm{~m}$ asl) and
\end{abstract}

Communicated by C. Ammer.

\section{P. Affolter}

Institute of Geography, University of Berne, Hallerstrasse 12,

3012 Bern, Switzerland

U. Büntgen $(\bowtie) \cdot$ A. Rigling · P. Weber · D. Frank

Swiss Federal Research Institute WSL, Zürcherstrasse 111, 8903

Birmensdorf, Switzerland

e-mail: buentgen@wsl.ch

U. Büntgen · D. Frank

Oeschger Centre for Climate Change Research, Erlachstrasse 9a, 3012 Bern, Switzerland

\section{J. Esper}

Department of Geography, Johannes Gutenberg University, Becherweg 21, 55099 Mainz, Germany

J. Luterbacher

Department of Geography, Justus-Liebig-University,

Senckenbergstrasse 1, 35390 Giessen, Germany species-specific mean time-series. These records were compared with temperature, precipitation, and drought (scPDSI) data. Among the altitudinal records, the colline chronologies showed highest correlation with June precipitation and scPDSI (0.5 and 0.7). Altitudinal effects, via control on climatic conditions, were superimposed upon species-specific characteristics in affecting tree growth and response to moisture variations. In particular, species-specific differences affected the significance level of drought response, with decreasing drought sensitivity towards higher elevations. Growth conditions were found to be optimal at $\sim 1,300 \mathrm{~m}$ asl, with precipitation/drought limiting tree growth below and temperature above. Common years of extreme drought and low growth for the colline sites occurred in 1921, 1944, 1976, 1992, and 1998. Our results demonstrate the potential of lower elevation conifers for reconstructing long-term changes in Alpine hydro-climate.

Keywords Alpine drought · Tree-ring width . Hydro-climate · Dendroclimatology

\section{Introduction}

Regional- to global-scale climate variability within the past decades is now regarded to exceed natural envelopes of more than the last millennium (IPCC 2007). Particular emphasis has been placed on temperature fluctuations as these are most directly tied to changes in radiative forcing and due to relatively high spatial autocorrelation may be reasonably well reconstructed with a more sparse data network (Esper et al. 2002; Cook et al. 2004). However, in climate change scenarios, not only rising temperatures are projected, but also shifts in the hydrological cycle are expected or even already observed (Huntington 2005; Zhang et al. 2007). 
In this regard, Zhang et al. (2007) estimated that anthropogenic forcing contributed significantly to the observed increase in annual precipitation in the Northern Hemisphere mid-latitudes (e.g., Treydte et al. 2006) and to drying in subtropical regions (e.g., Esper et al. 2007). Due to the local character of precipitation variability, investigations are, however, more complex, and trend predictions remain difficult, particularly on the regional scale (Stott et al. 2006; Matti et al. 2009). As future short- to long-term variations in water availability are arguably much more important to society and ecosystem functioning than temperature variations (IPCC 2007), current research priorities include the quantification of long-term changes in moisture availability from spatially well-distributed locations, as well as the assessment of drought and pluvial conditions on ecosystem functioning (Straile and Stenseth 2007).

Within the greater Alpine region (GAR), well-homogenized instrumental precipitation measurements that provide reliable insight into regional variability are available over the last decades to centuries, with high-elevation measurements being particularly prone to error (e.g., Efthymiadis et al. 2007; Auer and 31 Co-authors 2007 and references therein). Similarly, van der Schrier et al. (2006) introduced the self-calibrating palmer drought severity index (scPDSI) to investigate 20th century variations in soil moisture availability across continental Europe. A revised version including a snow model was released for the Alpine arc (van der Schrier et al. 2007).

Nevertheless, to assess precipitation totals further back in time-and particularly prior to large-scale industrialization-annually resolved information from indirect archives, so-called proxy data is required. Such records can include precipitation indices based on documentary evidence (see Brázdil et al. 2005, for a review; Gimmi et al. 2007) and various precipitation natural archives (Pauling et al. 2006). Tree-ring data, which have been prominently used to reconstruct temperature variations over the GAR (e.g., Frank and Esper 2005b; Büntgen et al. 2005, 2006, 2008, 2009b), can be a useful tool to also obtain information on past drought and/or precipitation changes. The ability for tree rings to capture temperature or moisture variations depends upon the given site ecology (Fritts 1976; Nemani et al. 2003; Neuwirth et al. 2004; Büntgen et al. 2007). That is, measurements from trees growing near their thermal growth limit (upper or latitudinal treeline) reflect temperature variations, and conversely measurements from trees growing under warm and/ or arid conditions mirror drought fluctuations.

The only reconstruction that allows inner Alpine precipitation variability to be retained, originates from the Austrian Alps, Tyrol (Oberhuber and Kofler 2002). Other proximal tree ring-based precipitation/drought reconstructions include that from Wilson et al. (2005) for the Bavarian forest and from the Vienna basin (Brázdil et al.
2002; Leal et al. 2008; Strumia et al. 1997 (see Büntgen et al. 2009a) for more information on these studies and an overview of Central European hydro-climatic records). From the spatial distribution of these existing records and considering the short spatial de-correlation length typical for moisture changes, additional locations are necessary to provide a better understanding of European-scale hydroclimatic variability (Pauling et al. 2006; Matti et al. 2009; Büntgen et al. 2009c).

In this regard, tree-ring networks that assess growth response to hydro-climatology are of particular importance. Schweingruber and Nogler (2003) analyzed precipitation signals in a tree-ring network including the southern German Black Forest, the Vosges Mountains (northeastern France), the Central Plateau, Jura, and northern Pre-Alps (both Switzerland). Leal et al. (2008) and Strumia et al. (1997) analyzed the growth sensitivity of numerous low-elevation pine sites in Austria. Other studies focused on climatic forcing of tree growth along various ecological gradients in inner Alpine valleys (Kienast et al. 1987; Oberhuber et al. 1998; Rigling et al. 2001, 2002, 2003; Neuwirth et al. 2004; Eilmann et al. 2006; Weber et al. 2007). More systematic network analyses that would allow the reconstruction of past drought changes are, however, scarce (Büntgen et al. 2009c). Investigations on pine mortality (Bigler et al. 2006; Dobbertin and Rigling 2006) and displacement by oak (Weber et al. 2007, 2008) in the Swiss Valais suggest an increasing effect of drought events to this conifer species. Although an intensification of extreme climate conditions is expected for sensitive regions like the Alps (Wanner et al. 2000), a large-scale assessment of precipitation variability is still missing. The same accounts for a basic assessment of extreme drought events on tree growth.

Here, we present the first step toward reconstructing drought variability in the Swiss Alps. Our study is restricted to the inner Alpine valley of the Valais, as local dry climate conditions suggest precipitation sensitive tree growth. Moreover, an altitudinal gradient can be studied from the valley bottom at $400-600 \mathrm{~m}$ asl up to the treeline at $\sim 2,300 \mathrm{~m}$ asl. Additional motivation derived from several tree-ring series that are already at disposal. In summary, we (1) develop a unique network of TRW data covering colline to sub-alpine elevations, (2) assess climate signals within this dataset, and (3) discuss altitudinal and species-specific patterns of conifer response to temperature, precipitation and drought.

\section{Materials and methods}

We complemented 22 existing TRW site chronologies from the Rhone valley-an inner alpine dry valley in the Swiss Canton Valais (Wanner et al. 2000)_ending in the 
1990s with data from 31 new TRW site chronologies continuing until 2005 (Table 1). The resulting network represents a substantial update compared with existing compilations and now covers a longitudinal west-east transect from Martigny to Fiesch spanning from $590 \mathrm{~m}$ to $1,570 \mathrm{~m}$ asl (Fig. 1). It comprises 1,605 TRW measurement series from four conifer species (Table 1): pine (Pinus sylvestris L.), larch (Larix decidua Mill.), spruce (Picea abies (L.) Karst.), and fir (Abies alba Mill.) hereinafter PISY, LADE, PCAB, and ABAL, respectively. The mean number of core samples per site is 28 with a minimum of 5 and a maximum of 135. Mean segment length per site is 96 years with a minimum of 43 and a maximum of 161 years.

Non-climatic biological/geometrical-induced age trends (Fritts 1976) were removed from the raw measurement series (though allowing inter-annual to multi-decadal scale variations to be preserved) using cubic smoothing spline detrending with a $50 \%$ cutoff at 150 years (Cook and Peters 1981). Even though longer term growth trends above multi-decadal time-scales are, however, not retained (Cook et al. 1995), Büntgen et al. (2009a) successfully applied this particular spline length on a similar dataset of droughtsensitive pine data from Slovakia. Further, the spectral properties in the TRW chronologies are likely to be similar to variations in the scPDSI due to the extended biological memory of TRW (Frank and Esper 2005a; Frank et al. $2007 \mathrm{a}, \mathrm{b})$ and the integration of lower frequency climatic and hydrological parameters in the scPDSI (Esper et al. 2007). For each site, measurement series were averaged to form chronologies based on a bi-weight robust mean, and truncated at a replication of at least five series to mitigate variance artifacts (Frank et al. 2007a, b), as well as noise from poorer representations of the population chronology (Wigley et al. 1984).

For growth/climate response analyses, the site chronologies were divided into four altitudinal master chronologies: colline $(<800 \mathrm{~m}$ asl, mean Rbar of site chronologies = 0.64), sub-montane (800-1,000 m asl, Rbar $=0.69)$, montane $(1,000-1,450 \mathrm{~m}$ asl, Rbar $=0.67)$, and sub-alpine $(>1,450 \mathrm{~m}$ asl, $R$ bar $=0.61)$. Moreover, the site chronologies were divided into four species-specific master chronologies: PISY, LADE, PCAB, and ABAL for which intercorrelation $R b a r$ is $0.63,0.66,0.71$ and 0.73 , respectively. The low-elevation colline chronology consists of four site chronologies (97 PISY series) covering the 1901-2002 period, whereas the sub-montane chronology includes 21 site chronologies (674 series, all species) covering the 18242005 period. The montane chronology combines 19 site chronologies (488 series, all species) over the period 17512005 and the sub-alpine chronology combines nine site chronologies (255 series, all species) over 1796-2005.
For climate response analysis, datasets of gridded $\left(0.5^{\circ} \times 0.5^{\circ}\right)$ monthly temperature and precipitation (CRUTS 2.1; Mitchell and Jones 2005) and scPDSI (van der Schrier et al. 2007) were used. Data from one grid point nearby Sierre $\left(46^{\circ} 18^{\prime} \mathrm{N} / 7^{\circ} 31^{\prime} \mathrm{E}\right)$ were considered for comparison over the 20th century and expressed as anomalies with respect to the 1961-1990 climatology. The altitudinal and species-specific chronologies were correlated against monthly climate data over the common 1932-1979 period and using an 18-month window from May of the year prior to tree growth until October of the vegetation period. Correlation coefficients were calculated along with the corresponding $95 \%$ significance levels corrected for lag-1 autocorrelation of each dataset (Trenberth 1984).

\section{Results}

Low- and mid-elevation chronologies showed significant $(P<0.05)$ negative relationships with temperature of previous year August and September (Fig. 2a). The colline chronology correlated negatively with current year AprilMay and July-August temperatures, whereas the mid-elevation chronologies indicated slightly negative correlations to current year May (sub-montane and montane) and August (sub-montane) temperatures. The high-elevation sub-alpine chronology revealed non-significant $(P>0.05)$ correlations with temperature, although a certain tendency toward positive values from current August to October was indicated.

For precipitation, significant TRW responses were found by the sub-montane chronology to previous year JulyAugust and by the sub-alpine chronology to August (Fig. 2b). The low-elevation colline chronology correlated slightly positive with January and highly positive with June-July precipitation in the year of ring formation. Moreover, the sub-montane and the montane chronology indicated good agreement with June precipitation.

Comparison of the altitudinal master chronologies with scPDSI data (Fig. 2c) resulted in highest coefficients and a reduced monthly difference due to increased autocorrelation of the scPDSI metric. Low- to mid-elevation chronologies correlated positively with previous year July-December scPDSI. The sub-montane and the montane chronologies showed decreasing correlations with scPDSI in the current year, with non-significant coefficients obtained for the montane chronology in February, March, and August and for both chronologies in October. With June scPDSI, however, they both still showed high correlations ( 0.59 and 0.48). The colline chronology indicated a strong relationship to current year scPDSI data with highest coefficients in the summer months June and July (0.73 and 0.72). The 
Table 1 Characteristics of the site chronologies ordered by altitude

\begin{tabular}{|c|c|c|c|c|c|c|c|c|}
\hline & Site location & $\mathrm{m}$ asl & Series & Period $>5$ & Species & Rbar & MSL & Source \\
\hline \multirow[t]{4}{*}{$<800 \mathrm{~m}$ asl (colline) } & Lens A & 695 & 18 & 1911-2001 & PISY & 0.643 & 63.9 & Weber \\
\hline & LWF Visp 627 & 704 & 20 & 1932-1996 & PISY & 0.649 & 43.3 & Cherubini \\
\hline & Eschwald A & 710 & 39 & 1928-2001 & PISY & 0.477 & 61.2 & Weber \\
\hline & Bramois B & 735 & 20 & 1901-2001 & PISY & 0.728 & 83.2 & Weber \\
\hline \multirow{21}{*}{$\begin{array}{c}800-1,000 \mathrm{~m} \text { asl } \\
\text { (sub-montane) }\end{array}$} & Salgesch A & 825 & 19 & $1846-2001$ & PISY & 0.593 & 82.8 & Weber \\
\hline & Les Arbepins 257 & 840 & 18 & 1846-1979 & PISY & 0.704 & 103.6 & Kienast \\
\hline & Susten Zänd 469 & 840 & 38 & 1773-1980 & РCAB & 0.827 & 92.9 & Schweingruber \\
\hline & Susten Zänd 470 & 840 & 6 & 1847-1980 & ABAL & 0.798 & 84.5 & Schweingruber \\
\hline & Susten Zänd 471 & 840 & 17 & 1824-1980 & ABAL & 0.871 & 112.3 & Schweingruber \\
\hline & Riddes & 860 & 28 & 1892-2005 & PISY & 0.717 & 89.3 & Affolter \\
\hline & Riddes & 860 & 30 & 1887-2005 & LADE & 0.703 & 101.3 & Affolter \\
\hline & Eschwald B & 865 & 26 & 1909-2001 & PISY & 0.658 & 55.2 & Weber \\
\hline & Stalden & 880 & 135 & 1838-2003 & PISY & 0.600 & 88.2 & Rigling \\
\hline & Boutieu 66 & 880 & 32 & 1886-1979 & PISY & 0.550 & 76.5 & Kienast \\
\hline & Eponde 136 & 880 & 5 & 1854-1979 & PISY & 0.685 & 118.4 & Kienast \\
\hline & Crete 117 & 890 & 26 & 1839-1979 & PCAB & 0.733 & 103.0 & Kienast \\
\hline & Hopflsteig & 900 & 36 & 1796-2005 & LADE & 0.705 & 117.3 & Affolter \\
\hline & Hopflsteig & 900 & 24 & 1882-2005 & PCAB & 0.727 & 76.2 & Affolter \\
\hline & Hopflsteig & 900 & 18 & 1816-2005 & LADE & 0.686 & 127.7 & Affolter \\
\hline & Salgesch & 900 & 22 & 1793-2001 & PISY & 0.590 & 105.3 & Eilmann \\
\hline & Salgesch & 910 & 111 & 1834-2003 & PISY & 0.701 & 117.1 & Rigling \\
\hline & Bramois C & 930 & 20 & 1892-2001 & PISY & 0.647 & 83.2 & Weber \\
\hline & Eggerberg A & 950 & 20 & 1867-2001 & PISY & 0.606 & 75.8 & Weber \\
\hline & Eschwald C & 960 & 20 & 1910-2001 & PISY & 0.644 & 56.0 & Weber \\
\hline & Salgesch B & 980 & 23 & 1851-2001 & PISY & 0.718 & 97.3 & Weber \\
\hline \multirow{19}{*}{$\begin{array}{l}>1,000-1,450 \mathrm{~m} \text { asl } \\
\quad(\text { montane })\end{array}$} & LWF Lens 621 & 1,064 & 20 & 1821-1997 & PISY & 0.719 & 106.0 & Cherubini \\
\hline & Eggerberg B & 1,075 & 22 & 1868-2001 & PISY & 0.524 & 57.1 & Weber \\
\hline & Deischbach & 1,080 & 52 & $1841-2005$ & PISY & 0.621 & 109.3 & Affolter \\
\hline & Salgesch C & 1,120 & 16 & 1899-2001 & PISY & 0.608 & 58.2 & Weber \\
\hline & Lens C & 1,150 & 18 & 1819-2001 & PISY & 0.690 & 106.6 & Weber \\
\hline & Eggerberg $\mathrm{C}$ & 1,200 & 18 & 1911-2001 & PISY & 0.518 & 74.5 & Weber \\
\hline & Creux du Dailley mittel & 1,200 & 9 & 1855-1979 & PCAB & 0.791 & 115.0 & Kienast \\
\hline & Pres des Champs 380 & 1,220 & 27 & 1884-1979 & PCAB & 0.692 & 71.8 & Kienast \\
\hline & Bannwald Süd 47 & 1,230 & 28 & 1814-1980 & PCAB & 0.829 & 125.2 & Schweingruber \\
\hline & Bannwaid Süd 48 & 1,230 & 27 & $1810-1981$ & ABAL & 0.770 & 101.3 & Schweingruber \\
\hline & Bannwald Süd 49 & 1,230 & 25 & 1878-1980 & ABAL & 0.797 & 84.8 & Schweingruber \\
\hline & Bannwald Nord 45 & 1,240 & 7 & 1798-1980 & PCAB & 0.704 & 88.0 & Schweingruber \\
\hline & Bannwald Nord 45 & 1,240 & 24 & $1874-1980$ & ABAL & 0.741 & 87.5 & Schweingruber \\
\hline & Creux du Dailley 119 & 1,240 & 15 & $1751-1979$ & PISY & 0.709 & 160.7 & Kienast \\
\hline & Ritena & 1,260 & 34 & $1820-2005$ & PISY & 0.651 & 139.6 & Affolter \\
\hline & Ritena & 1,260 & 36 & 1874-2005 & LADE & 0.744 & 109.4 & Affolter \\
\hline & Savièse & 1,440 & 32 & 1820-2005 & PISY & 0.485 & 98.8 & Affolter \\
\hline & Savièse & 1,440 & 32 & 1906-2005 & PCAB & 0.602 & 48.6 & Affolter \\
\hline & Scheni Biela & 1,450 & 46 & $1757-2005$ & PISY & 0.447 & 157.8 & Affolter \\
\hline \multirow{4}{*}{$\begin{array}{r}>1,450 \mathrm{~m} \text { asl } \\
\text { (sub-alpine) }\end{array}$} & Jeizinen & 1,500 & 56 & $1848-2005$ & LADE & 0.566 & 92.5 & Affolter \\
\hline & Ovronnaz & 1,500 & 11 & 1829-2005 & LADE & 0.632 & 100.5 & Affolter \\
\hline & Ovronnaz & 1,500 & 12 & $1843-2005$ & ABAL & 0.483 & 85.1 & Affolter \\
\hline & Ovronnaz & 1,500 & 43 & $1832-2005$ & LADE & 0.611 & 90.5 & Affolter \\
\hline
\end{tabular}


Table 1 continued

\begin{tabular}{lllllllll}
\hline Site location & $\mathrm{m}$ asl & Series & Period $>5$ & Species & Rbar & MSL & Source \\
\hline Mittleri Hellalawald 294 & 1,510 & 27 & $1796-1980$ & PCAB & 0.619 & 134.9 & Schweingruber \\
Mittleri Hellalawald 294 & 1,510 & 30 & $1818-1980$ & ABAL & 0.637 & 108.8 & Schweingruber \\
Chable des Trois Besses & 1,520 & 28 & $1816-1719$ & PCAB & 0.587 & 129.6 & Kienast \\
Torrent des Croix 491 & 1,540 & 18 & $1835-1979$ & PISY & 0.655 & 122.0 & Kienast \\
Bisse de Saxon 59 & 1,570 & 30 & $1861-1979$ & PCAB & 0.699 & 104.9 & Kienast \\
\hline
\end{tabular}

Period time-span covered by at least 5 series, Rbar inter-series correlation, $M S L$ mean segment length

Fig. 1 Location of the TRW sites, classified with respect to elevation, species, and replication

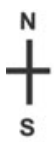

${ }_{s}^{N}$

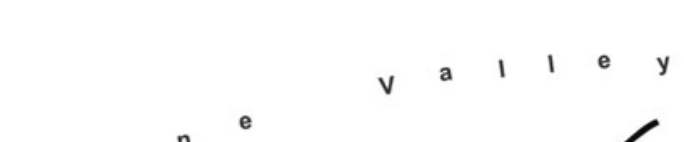

Münster

h

R

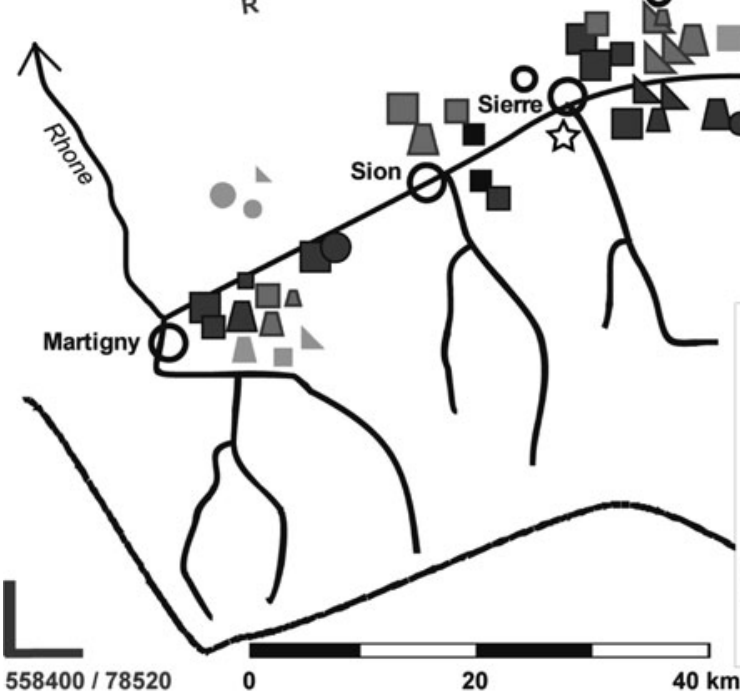

SITE CHRONOLOGIES

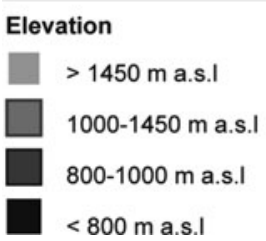

Species

Replication

ㅁ $>10$ trees

$\square \quad 10-20$ trees

$\square>20$ trees Larix decidua Mill.

Picea abies (L.) Karst.

Abies alba Mill.
Gridpoint Position

ClimATE DATA

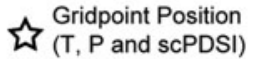

sub-alpine chronology did not correlate significantly with scPDSI.

A comparison of the low-elevation colline chronologyconsisting of PISY only-with June scPDSI (Fig. 3a) emphasized common deviations in extreme drought events: 1921, 1944, 1976, 1992, and 1998. The correlation between growth and June scPDSI was further analyzed using a 31year moving window approach. For the period 1932-1979 (common to all TRW and climate datasets), TRW data corresponded with the scPDSI in high- to low-frequency domains; coefficients up to 0.73 were reached. Shorter time spans at the beginning and the end of the full overlapping period (1902-2001) revealed weaker relationships-sample replication of the colline chronology is low before 1929 and after 1995 (Fig. 3b).

With respect to species composition, PISY data indicated strongest coherency with the scPDSI (Fig. 4a). Correlations were positive over all seasons, with overall less similarity found with prior May-June and current October. PCAB showed also good agreement with May-December scPDSI in the year prior to tree growth and in current year January-July. The LADE chronology revealed an overall reduced positive relation to drought. Coefficients were only significant with previous year November-December, as 
Fig. 2 Correlation (1932-1979) between altitudinal monthly a temperature, b precipitation, and $\mathbf{c}$ scPDSI data from previous year May to current year October. Horizontal lines are 95\% significance levels corrected for lag-1 autocorrelation chronologies and gridded
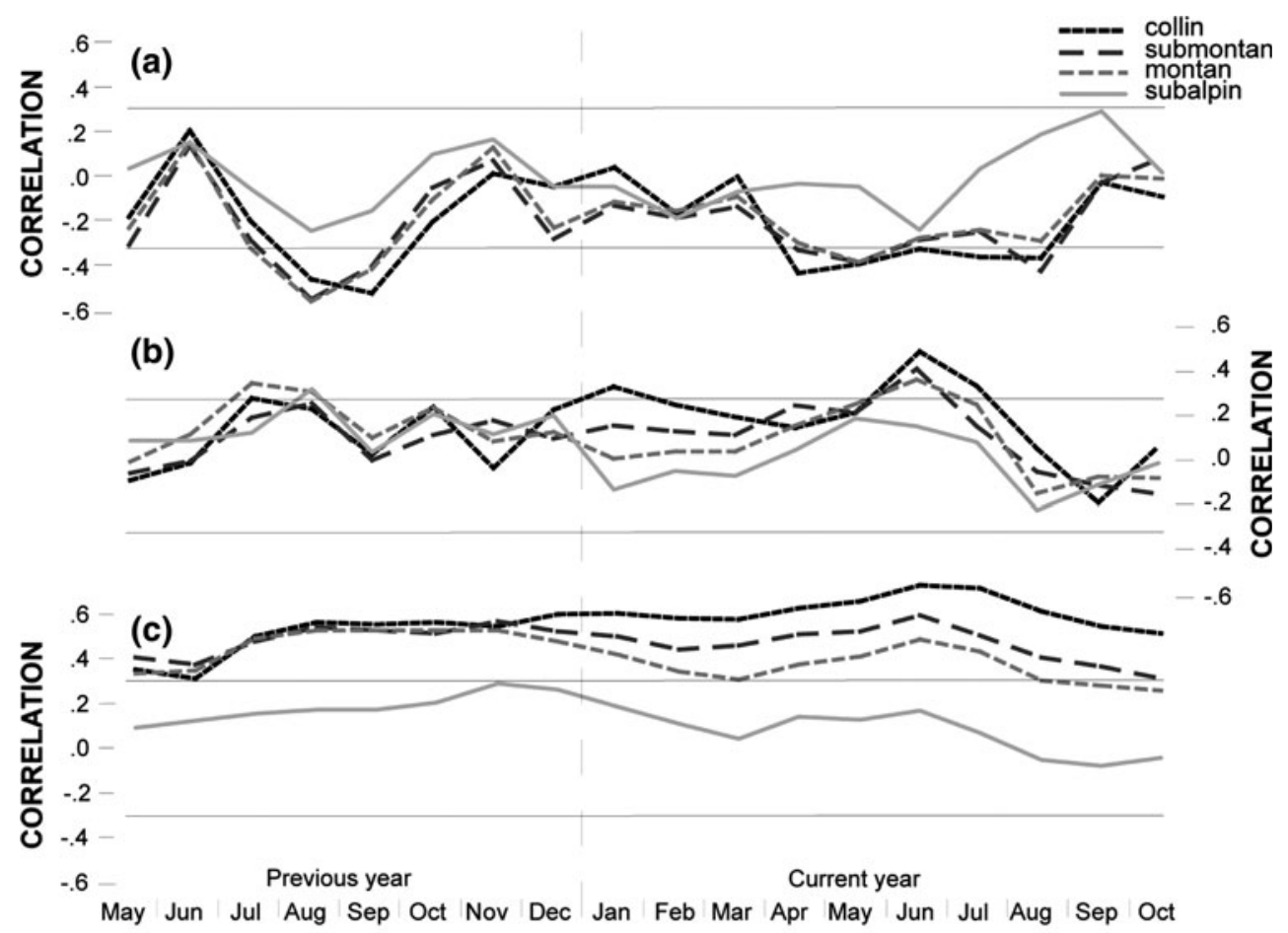

MONTHLY TARGETS

Fig. 3 a Comparison of the colline chronology (black dashed) and June scPDSI (gray). The TRW proxy was scaled (i.e., their variance and mean adjusted) to the climatic target (1901-2002), black dots indicate their 31-year moving correlations and $\mathbf{b}$ TRW sample replication is indicated

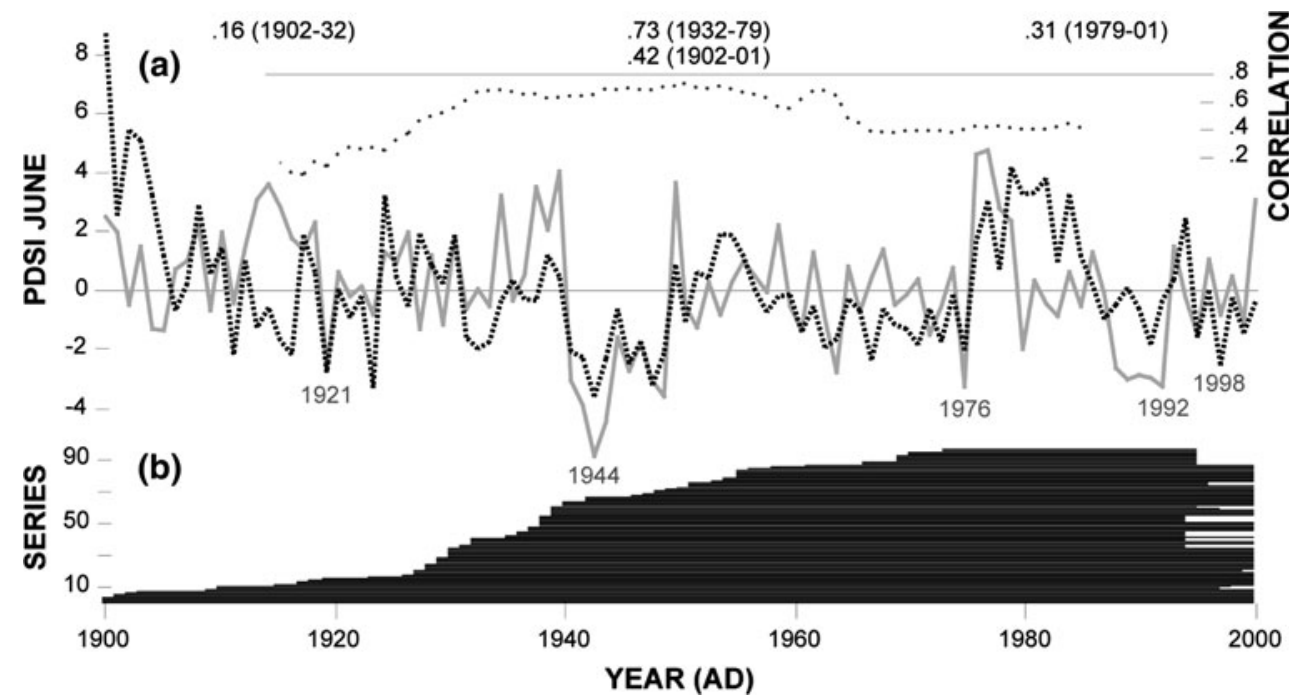

well as with April and June of the vegetation period. ABAL even did not show any significant correlation except with previous year September-November. For a better understanding of the obtained species-specific responses, chronologies were additionally distinguished in high (montane and sub-alpine) and low (colline and sub-montane) altitudes (Fig. 4b). In comparison with the June scPDSI, chronologies from lower elevation showed consistently higher correlations than those from higher elevations, independent of the species used.
To further explore frequency-dependent relationships between the altitudinal proxies and scPDSI targets, treering and instrumental data were high-, and low-pass filtered. Low-frequency variations correlated higher for the low- to mid-elevation chronologies. In both the lowand high-frequency domain, the strongest relation was found between the colline chronology and the scPDSI (0.8 in August and 0.68 in June, respectively), whereas the sub-alpine chronology did not correlate significantly at all. 
Fig. 4 a Correlations between the species-specific TRW chronologies and scPDSI data from previous year May to current year October. b Speciesand altitudinal-specific growth response patterns to June scPDSI
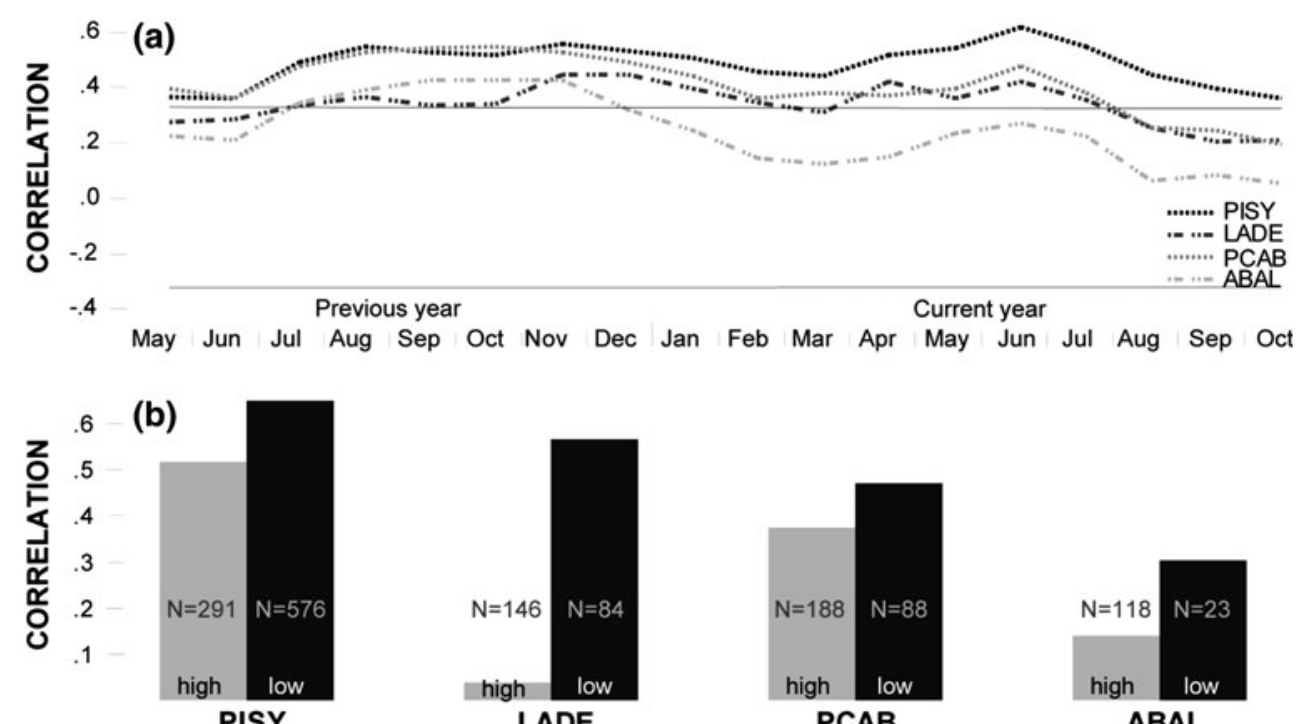

PCAB

ABAL

\section{Discussion}

The altitudinal- and species-specific master chronologies integrate varying quantities of site chronologies with unequal replication, time cover, and segment length (Table 1). Such heterogeneity most likely affects the identification and quantification of climatic signals. The master chronologies, however, contain a high degree of common variability caused by a universal forcing (Figs. 2a-c), in line with former studies using smaller data sub-sets from the same region (e.g., Kienast et al. 1987; Rigling et al. 2002; Weber et al. 2007). Some of the chronologies from lower elevations cover rather short periods during the 20th century. Finding long-lived trees at lower elevations remains difficult due to extensive past anthropogenic impacts within the Rhone valley, including clear-cutting and pasturing (Gimmi et al. 2008). Furthermore, the lower elevation forests were frequently replaced by vineyards or affected by natural hazards, such as rock fall, debris flow, and avalanches (e.g., Gärtner et al. 2004).

The altitudinal master chronologies indicated characteristic climate-growth relationships, namely drought sensitivity at lower elevations and a tendency toward temperature-limited growth at higher elevations. Reduced water availability during the growing season at lower altitudes (Rigling et al. 2002; Eilmann et al. 2006; Weber et al. 2007) and growth-limiting temperatures at high elevations (Büntgen et al. 2005, 2006, 2008, 2009b) are likely also the key reasons for substantial productivity changes with elevation (Neuwirth et al. 2004), including enhanced growth rates at $\sim 1,300 \mathrm{~m}$ asl, and clearly lower growth rates below $1,000 \mathrm{~m}$ asl and toward the upper treeline (Fig. 5). These results are in agreement with patterns initially described by Kienast et al. (1987), who assessed altitudinal gradients at a few sites in the Rhone valley and with Frank and Esper (2005a), who showed a decrease in
Fig. 5 Absolute growth rates of the low- to mid-altitudinal master chronologies and TRW data from higher elevations (Büntgen et al. 2005, 2006; LÖ1 in 1,600-2,100 $\mathrm{m}$ asl and LÖ2 in $2,100-2,300 \mathrm{~m}$ asl).

Chronologies $<1,000 \mathrm{~m}$ asl are limited by soil moisture water availability and chronologies $>1,450 \mathrm{~m}$ asl by temperature of the growing season, with the overall growth optimum being reached $\sim 1,250 \mathrm{~m}$ asl. Growth rates $(\mathrm{mm} / \mathrm{year})$ are expressed as the average values computed over the 50 innermost rings (cambial age 0-50) per subset

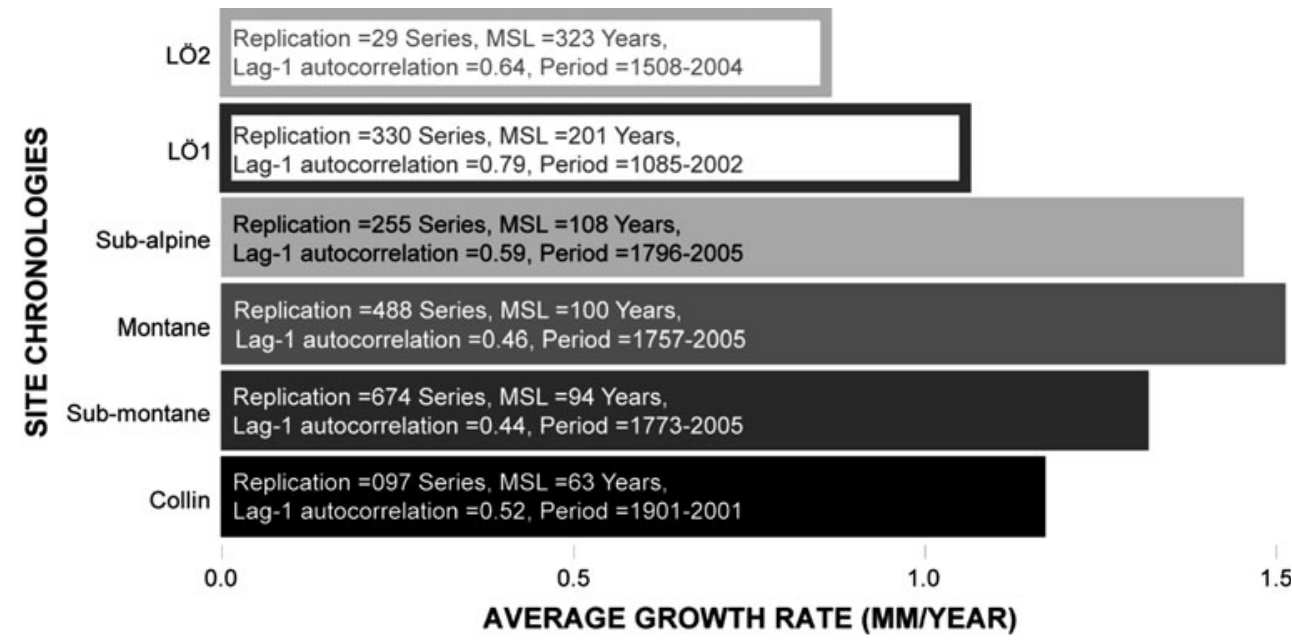


(positive) temperature response toward lower elevations in a multi-species network across the Alps.

For different reasons, the colline PISY chronology showed slightly lower correlations with June scPDSI at the beginning and the end of the 20th century (Fig. 3). Low replication likely contributed to the reduced correlation coefficients during the early period, whereas the number of samples significantly increased from the 1930s to present. A higher proportion of juvenile wood (Esper et al. 2008) and ceasing growth in dying PISY trees (Bigler et al. 2006; Weber et al. 2008), may additionally have led to decreasing significance at the end of the analysis period. Nevertheless, the strong correlation over 50 years between the low-elevation colline chronology and the June scPDSI indicated that radial growth is mainly controlled by moisture availability at sites $<1,000 \mathrm{~m}$ asl. This is well in line with findings of Dobbertin et al. (2005) who showed droughtinduced PISY mortality at lower elevations whereas in higher altitudes ( $>1,000 \mathrm{~m}$ asl) mortality occurred less frequent. In contrast, the sub-alpine chronology did not reveal significant correlations with the drought index nor with temperature of the vegetation period, suggesting that the sub-alpine zone acts as transition zone where climate is not exceptionally dry or cold and growth conditions for conifers are not yet constraining (Kienast et al. 1987). The moderate levels of both temperature and moisture constraints at these mid-elevations are likely responsible for the overall high biomass productivity (Fig. 5).

Moreover, the uneven distribution of species within the network made it difficult to determine the influence of species relative to altitude on the obtained tree growth/ climate interactions. Schweingruber and Nogler (2003) attribute a strong relationship between climate and maximum ring width to species-specific differences in the onset and duration of radial growth in trees across the Central European temperate zone. While multiple factors are known to influence tree growth under temperate climate conditions, more distinct factors are hypothesized to control climatically extreme sites in regions such as in the inner Alpine Rhone valley (Rigling et al. 2002). Since our dataset was restricted to dry sites only, a common drought response of all four species at altitudes $<1,000 \mathrm{~m}$ asl was to be expected. Similar correlation patterns of the speciesspecific time-series, although variable in strength, clearly confirmed the main growth-controlling factor across the network to be soil moisture availability. While PISY responded very strongly to drought, ABAL revealed a reduced hydro-climatic signal. These differences might be explained by species-specific response strategies to varying climatic conditions. In fact, PISY that mainly grows on shallow soils reacts different to drought variability than ABAL, commonly growing on deeper soils. The speciesspecific growth response to different drought levels thus transforms into different radial growth patterns (Frank and Esper 2005a; Rigling et al. 2001). The classification of species-specific chronologies into high- and low-elevation subsets finally implied a strong influence of altitude on drought response. The lack of drought response in LADE at higher elevations might be explained by the fact, that in these altitudes potential evapotranspiration is lowest (see Friedrichs et al. 2009 for a detailed description of drought-, cloud-cover-, and vapor pressure-effects on forest productivity). In addition, it remains unclear how well the scPDSI metric can represent soil moisture availability of the highelevation sites, because climatic input variables mainly derived from low-elevation climate stations. This might be relevant for precipitation but less for spatially robust temperature records, both of which feed into the improved scPDSI drought index used.

Due to the nature of the initially developed PDSI metric (e.g., van der Schrier et al. 2006), one should consider its limitation in robustly reflecting drought fluctuations over mountainous regions, such as the Alpine arc. This constrain is mainly related to the algorithm, which assumed all precipitation-independent of the seasonal cycle - to be in the liquid phase. The herein used scPDSI introduced by van der Schrier et al. (2007), however, included a snow accumulation and melt model in the water balance calculations to overcome this limitation. High correlation coefficients between the colline TRW chronology and the summer scPDSI confirmed its correctness as a drought metric for this region.

\section{Conclusions}

Data from colline and sub-montane sites in the Rhone valley, Valais, Switzerland contained a clear summer drought signal with expression of the drought events in 1921, 1944, 1976, 1992, and 1998. The signal was strongest in PISY chronologies and less pronounced in higher elevations, pointing at the potential of both, living and historic material from lower elevation sites for drought reconstruction purposes. The statistical data characteristics herein provided a useful impetus to provenance ancient construction timbers to subsequently extend the database for drought reconstructions back in time. Improved understanding of past drought variability in the Alps will contribute to the analysis of shifts in the hydrological cycle, which is highly relevant for any prediction of future climate trends. In addition, this study demonstrated how drought limitations impact radial growth, which is of relevance for understanding forest productivity and carbon sequestration in a changing environment.

Acknowledgments We thank F. Schweingruber, F. Kienast, B. Eilmann, and P. Cherubini for providing tree-ring data. A. Verstege, 
D. Nievergelt, and M. Schmidhalter joint fieldwork. U. B. and D. F. were supported by the EC project Millennium (\#017008) and the Swiss SNF project NCCR Climate. P. W. was supported by the Velux foundation. J. L. acknowledges support from the 7th EU Framework program ACQWA (Assessing Climate Impacts on the Quantity and Quality of Water, http://www.acqwa.ch/, \# 212250).

\section{References}

Auer I, 31 Co-authors (2007) HISTALP-historical instrumental climatological surface time series of the Greater Alpine Region. Int J Climatol 23:1-26

Bigler C, Bräker OU, Bugmann H, Dobbertin M, Rigling A (2006) Drought as an inciting mortality factor in Scots Pine stands of the Valais, Switzerland. Ecosystems 9:330-343

Brázdil R, Stepankova P, Kyncl T, Kyncl J (2002) Fir treering reconstruction of March-July precipitation in southern Moravia (Czech Republic), 1376-1996. Climate Res 20:223-239

Brázdil R, Pfister C, Wanner H, von Storch H, Luterbacher J (2005) Historical climatology in Europe-the state of the art. Climatic Change 70:363-430

Büntgen U, Esper J, Frank DC, Nicolussi K, Schmidhalter M (2005) A 1052-year tree-ring proxy for Alpine summer temperatures. Clim Dyn 25:141-153

Büntgen U, Frank DC, Nievergelt D, Esper J (2006) Summer temperature variations in the European Alps, A.D. 755-2004. J Clim 19:5606-5623

Büntgen U, Frank DC, Kaczka RJ, Verstege A, Zwijacz-Kozica T, Esper J (2007) Growth responses to climate in a multi-species tree-ring network in the Western Carpathian Tatra Mountains, Poland and Slovakia. Tree Physiol 27:689-702

Büntgen U, Frank DC, Wilson R, Carrer M, Urbinati C, Esper J (2008) Testing for tree-ring divergence in the European Alps. Global Change Biol 14:2443-2453

Büntgen U, Brázdil R, Frank DC, Esper J (2009a) Three centuries of Slovakian drought dynamics. Clim Dyn. doi:10.1007/s00382009-0563-2

Büntgen U, Frank D, Carrer M, Urbinati C, Esper J (2009b) Improving Alpine summer temperature reconstructions by increasing sample size. TRACE 7:36-43

Büntgen U, Frank D, Franke J, Wilson R, Gonzalez-Rouco F, Esper J (2009c) Proxy number and location to reconstruct European climate variability. Clim Res (in review)

Cook ER, Peters K (1981) The smoothing spline: a new approach to standardizing forest interior tree-ring width series for dendroclimatic studies. Tree-Ring Bull 41:45-53

Cook ER, Briffa KR, Meko DM, Graybill DA, Funkhouser G (1995) The 'segment length curse' in long tree-ring chronology development for palaeoclimatic studies. The Holocene 5:229-237

Cook ER, Esper J, D'Arrigo R (2004) Extra-tropical northern hemisphere temperature variability over the past 1000 years. Quat Sci Rev 23:2063-2074

Dobbertin M, Rigling A (2006) Mistletoe (Viscum album ssp. austriacum) contributes to the Pinus sylvestris L. decline in the Rhone Valley of Switzerland. Forest Pathol 36:309-322

Dobbertin M, Mayer P, Wohlgemuth T, Feldmeyer-Christe E, Graf U, Zimmermann N, Rigling A (2005) The decline of Pinus sylvestris L. forests in the Swiss Rhone valley-a result of drought stress? Phyton 45:153-156

Efthymiadis D, Jones PD, Briffa KR, Böhm R, Maugeri M (2007) Influence of large-scale atmospheric circulation on climate variability in the Greater Alpine Region of Europe. J Geophys Res 112:D12104. doi:10.1029/2006JD008021
Eilmann B, Weber P, Rigling A, Eckstein D (2006) The influence of drought on the wood structure of Pinus sylvestris L. and Quercus pubescens Willd. in Valais, Switzerland. Dendrochronologia 23:121-132

Esper J, Cook ER, Schweingruber FH (2002) Low-frequency signals in long tree-ring chronologies and the reconstruction of past temperature variability. Science 295:2250-2253

Esper J, Frank DC, Büntgen U, Verstege A, Luterbacher J, Xoplaki E (2007) Long-term drought severity variations in Morocco. Geophys Res Lett 34:L17702. doi:10.1029/2007GL030844

Esper J, Niederer R, Bebi P, Frank DC (2008) Climate signal age effects-evidence from young and old trees in the Swiss Engadin. For Ecol Manag 255:3783-3789

Frank D, Esper J (2005a) Characterization and climate response patterns of a high-elevation, multi-species tree-ring network in the European Alps. Dendrochronologia 22:107-121

Frank D, Esper J (2005b) Temperature reconstructions and comparisons with instrumental data from a tree-ring network for the European Alps. Int J Climatol 25:1437-1454

Frank D, Esper J, Cook ER (2007a) Adjustment for proxy number and coherence in a large-scale temperature reconstruction. Geophys Res Lett 34:L16709. doi:10.1029/2007GL030571

Frank D, Büntgen U, Böhm R, Maugeri M, Esper J (2007b) Warmer early instrumental measurements versus colder reconstructed temperatures: shooting at a moving target. Quat Sci Rev 26:3298-3310

Friedrichs D, Büntgen U, Esper J, Frank D, Neuwirth B, Löffler J (2009) Complex climate controls on 20th century oak growth in Central-West Germany. Tree Physiol 29:39-51

Fritts HC (1976) Tree rings and climate. Academic Press, London

Gärtner H, Esper J, Rigling A, Treydte K, Cherubini P (2004) Geomorphologie und Jahrringe-Feldmethoden in der Dendrogeomorphologie. Schweizerische Zeitschrift für Forstwesen 155:198-207

Gimmi U, Luterbacher J, Pfister C, Wanner H (2007) A method to reconstruct long precipitation series using systematic descriptive observations in weather diaries: the example of the precipitation series for Bern, Switzerland (1760-2003). Theor Appl Climatol 87:185-197

Gimmi U, Burgi M, Stuber M (2008) Reconstructing anthropogenic disturbance regimes in forest ecosystems: a case study from the Swiss Rhone Valley. Ecosystems 11:113-124

Huntington GT (2005) Evidence for intensification of the global water cycle: review and synthesis. J Hydrol 319:83-95

IPCC (2007) Climate Change 2007: the physical science basis. Contribution of working group I to the fourth assessment report of the IPCC. Cambridge University Press, Cambridge, United Kingdom and New York

Kienast F, Schweingruber FH, Braeker OU, Schaer E (1987) Treering studies on conifers along ecological gradients and the potential of single-year analyses. Can J Forest Res 17:683-696

Leal S, Eamus D, Grabner M, Wimmer R, Cherubini P (2008) Tree rings of Pinus nigra from the Vienna basin region (Austria) show evidence of change in climatic sensitivity in the late 20th century. Can J Forest Res 38:744-759

Matti C, Pauling A, Küttel M, Wanner H (2009) Winter precipitation trends for two selected European regions over the last 500 years and their possible dynamical background. Theor Appl Climatol 95:9-26

Mitchell TD, Jones PD (2005) An improved method of constructing a database of monthly climate observations and associated highresolution grids. Int J Climatol 25:693-712

Nemani RR, Keeling CD, Hashimoto H, Jolly WM, Piper SC, Tucker CJ, Myneni RB, Running SW (2003) Climate-driven increases in global terrestrial net primary production from 1982 to 1999 . Science 300:1560-1563 
Neuwirth B, Esper J, Schweingruber FH, Winiger M (2004) Site ecological differences to the climatic forcing of spruce pointer years from the Lötschental, Switzerland. Dendrochronologia 21:69-78

Oberhuber W, Kofler W (2002) Dendroclimatological spring rainfall reconstruction for an inner Alpine dry valley. Theor Appl Climatol 71:97-106

Oberhuber W, Stumböck M, Kofler W (1998) Climate-tree-growth relationships of Scots pine stands (Pinus sylvestris L.) exposed to soil dryness. Trees 13:19-27

Pauling A, Luterbacher J, Casty C, Wanner H (2006) Five hundred years of gridded high-resolution precipitation reconstructions over Europe and the connection to large-scale circulation. Clim Dyn 26:387-405

Rigling A, Waldner P, Forster T, Bräker OU, Pouttu A (2001) Ecological interpretation of tree ring width and intra-annual density fluctuations of Pinus sylvestris L. from dry sites of the central Alps and Siberia. Can J For Res 31:18-31

Rigling A, Bräker OU, Schneiter G, Schweingruber FH (2002) Intraannual tree-ring parameters indicating differences in drought stress of Scots pine forests within the Erico-Pinion in the Valais, Switzerland. Plant Ecol 163:105-121

Rigling A, Brühlhart $\mathrm{H}$, Bräker OU, Forster T, Schweingruber FH (2003) Irrigation effect on tree growth and vertical resin duct production of Pinus sylvestris L. on dry sites in the Central Alps, Switzerland. For Ecol Manag 163:105-121

Schweingruber FH, Nogler P (2003) Synopsis and climatological interpretation of Central European tree-ring sequences. Botan Helv 113:125-143

Stott P, Mitchell JFB, Allen MR, Delworth TL, Gregory JM, Meehl GA, Santer BD (2006) Observational constraints on past attributable warming and predictions of future global warming. J Clim 19:3055-3069

Straile D, Stenseth NC (2007) The North Atlantic oscillation and ecology: links between historical time-series, and lessons regarding future climate warming. Clim Res 34:259-262
Strumia G, Wimmer R, Grabner M (1997) Dendroclimatic sensitivity of Pinus Nigra Arnold in Austria. Dendrochronologia 15:129-137

Trenberth KE (1984) Some effects of finite sample size and persistence on meteorological statistics. Part I: Autocorrelations. Mon Weather Rev 112:2359-2368

Treydte KS, Schleser GH, Helle G, Frank DC, Winiger M, Haug GH, Esper J (2006) The 20th century was the wettest period in northern Pakistan over the past millennium. Nature 440:1179-1182

van der Schrier G, Briffa KR, Jones PD, Osborn TJ (2006) Summer moisture variability across Europe. J Clim 19:2828-2834

van der Schrier G, Efthymiadis D, Briffa KR, Jones PD (2007) European Alpine moisture variability for 1800-2003. Int J Climatol 27:415-427

Wanner H, Gyalistras D, Luterbacher J, Rickli R, Salvisberg E, Schmutz CH (2000) Klimawandel im Schweizer Alpenraum. Vdf Hochschulverlag AG, ETH, Zürich

Weber P, Bugmann H, Rigling A (2007) Radial growth responses to drought of Pinus sylvestris and Quercus pubescens in an inner Alpine dry valley. J Veg Sci 18:777-792

Weber P, Bugmann H, Fonti P, Rigling A (2008) Using a retrospective dynamic competition index to reconstruct forest succession. For Ecol Manag 254:96-106

Wigley TML, Briffa KR, Jones PD (1984) On the average of value of correlated time series, with applications in dendroclimatology and hydrometeorology. J Climatol Appl Meteorol 23:201-213

Wilson RJ, Luckman BH, Esper J (2005) A 500-year dendroclimatic reconstruction of spring-summer precipitation from the lower Bavarian forest region, Germany. In J Climatol 25:611-630

Zhang X, Zwiers FW, Hegerl GC, Lambert FH, Gillett NP, Solomon S, Stott PA, Nozawa T (2007) Detection of human influence on twentieth-century precipitation trends. Nature 448:461-465 